Counsellia: Jurnal Bimbingan dan Konseling

Volume 11 (2) 193 - 206 November 2021

ISSN: 2088-3072 (Print) / 2477-5886 (Online)

DOI: $10.25273 /$ counsellia.v11i2.10364

Available online at: http://e-journal.unipma.ac.id/index.php/JBK

\title{
Implementasi Bimbingan Dan Konseling Sebagai Penunjang Pembentukan Godly Character Mahasiswa Universitas Pelita Harapan
}

\author{
Susanna Kathryn ${ }^{1}$, Albert Andreas ${ }^{2}$, Donny Charles Chandra ${ }^{3}$, Wiryohadi \\ Wiryohadi $^{4}$, Apin Militia Christi ${ }^{5}$ \\ ${ }^{1}$ STT Bethel Indonesia, Jakarta \\ email: susannakathryn@sttbi.ac.id \\ ${ }^{2}$ STT Bethel Indonesia, Jakarta \\ email: anndreaslazarus@gmail.com \\ ${ }^{3}$ STT Bethel Indonesia \\ email: donychandra@sttbi.ac.id \\ ${ }^{4}$ STT Bethel Indonesia \\ email: wiryohadi@sttbi.ac.id \\ ${ }^{5}$ STT Bethel Indonesia, Jakarta \\ email: apinmilitiachristi@sttbi.ac.id
}

\begin{abstract}
Abstrak : Postmodern adalah corak berpikir yang mengedepankan pluralitas dan relativitas. Corak berpikir ini mempengaruhi juga seseorang dalam melakukan kebenaran Firman Tuhan dan teladan dalam membangun karakter pemuda. Penelitian ini bertujuan untuk melihat implementasi bimbingan dan konseling yang digunakan Universitas Pelita Harapan dalam menunjang perkembangan karakter mahasiswa dan mengidentifikasi faktor-faktor hambatan yang terjadi dalam pelaksanaannya. Hasil penelitian ini adalah implementasi yang digunakan memprioritaskan nilai-nilai firman Tuhan. Target yang ingin dicapai adalah membentuk mahasiswa untuk memiliki karakter ilahi. Proses bimbingan dan konseling diberikan melalui: (1) Penasihat akademik; (2) Organisasi rohani spiritual growth for student; (3) Asrama; (4) Lembaga konseling HOPE. Proses bimbingan dan konseling dilaksanakan dalam bentuk: (1) Pendekatan peraturan lembaga; (2) Pemberian nasihat; (3) Pemuridan; (4) Sistem learning by doing; (5) Bimbingan kolaboratif lembaga; dan (6) Support academic. Faktor-faktor yang menjadi penghambat adalah: (1) Kompetensi SDM yang belum memadai; (2) Mahasiswa yang kurang berminat kepada program bimbingan dan konseling; dan (3) Mahasiswa yang belum dapat bersifat dewasa.
\end{abstract}

Keywords: Bimbingan dan Konseling, Mahasiswa, Universitas Pelita Harapan, Karakter Mulia

Abstrac : Postmodern causes everything to be relative. Including in carrying out the truth of God's Word and example in building the character of youth. This study aims to look at the implementation of guidance and counseling used by Pelita Harapan University in supporting the development of student character and identify the obstacles 
that occur in its implementation. The result of this research is the implementation that is used to prioritize the values of God's word. The target to be achieved is to form students to have divine character. The process of guidance and counseling is provided through: (1) academic advisors; (2) spiritual organization spiritual growth for students; (3) Dormitory; (4) HOPE counseling agency. The guidance and counseling process is carried out in the form of: (1) Institutional regulatory approach; (2) Giving advice; (3) Discipleship; (4) learning by doing system; (5) Institutional collaborative guidance; and (6) academic support. The inhibiting factors are: (1) inadequate HR competencies; (2) Students who are less interested in the guidance and counseling program; and (3) Students who have not been able to become adults.

Keywords: Guidance and Counseling, Students, Universitas Pelita Harapan, Godly Character

Received; 26-09-2021 Accepted; 26-10-2021 Published ; 29-11-2021

Citation: Kathryn Susanna, Andreas Albert, Chandra Donny Charles, Wiryohadi Wiryohadi, Christi, Apin Militia. (2021). Implementasi Bimbingan Dan Konseling Sebagai Penunjang Pembentukan Godly Character Mahasiswa Universitas Pelita Harapan, 11(2), 193 - 206 Doi.org/10.25273/counsellia.v11i2.10364

\section{(cc) $\mathrm{BY}-\mathrm{NC}-\mathrm{SA}$}

Copyright @2021 Counsellia: Bimbingan dan Konseling

Published by Universitas PGRI Madiun. This work is licensed under the Creative Commons Attribution-NonCommercialShareAlike 4.0 International License

\section{PENDAHULUAN}

Generasi muda merupakan generasi yang akan meneruskan bangsa. Generasi muda memiliki fisik yang lebih kuat, dan juga pemikiran lebih inovatif serta kreatif dibandingkan dengan generasi sebelumnya. Generasi muda juga lebih akrab dengan teknologi yang ada pada masanya daripada generasi sebelumnya. Namun, seiring dengan berjalannya waktu, generasi yang baru akan terus bermunculan. Perubahan tersebut juga mengasilkan budaya yang baru pada generasi tersebut (Muqsith, 2019). Penggunaan handphone merupakan salah satu contoh bentuk perubahan yang terjadi pada saat ini. Bila pada generasi sebelumnya handphone bukanlah hal yang umum, pada saat ini handphone menjadi suatu hal yang sangat umum (Benyamin, Sinaga, \& Gracia, 2021). Teknologi tersebut semakin memberikan kemudahan dalam berbagai bidang. Namun, kemudahan tersebut tidak hanya memberikan dampak positif bagi generasi muda pada saat ini, namun juga memunculkan dampak negatif bagi generasi muda. Melalui handphone yang sudah menjadi seperti perpanjangan tangan mereka, berbagai informasi dari seluruh belahan dunia dapat mereka peroleh dengan sangat mudah. Informasi-informasi tersebut membentuk budaya baru bagi generasi ini. Mereka mengadopsi budaya-budaya dari tempat-tempat lain yang mungkin saja belum mereka ketahui apakah budaya tersebut merupakan budaya yang sesuai dengan karakter bangsa ini atau tidak. Budaya tersebut dapat dilihat dalam berbagai macam bentuk, seperti cara berpakaian, cara berbicara kepada orang-orang di lingkungan mereka, bahkan cara memperlakukan orang lain (Stillman \& Stillman, 2017). Hal tersebut menjadi berbahaya bila tidak mendapatkan pengawasan dari orangtua mereka. Bila generasi muda yang sedang dalam masa perkembangan dan belum dapat memilah dengan baik manakah nilai-nilai yang baik, kemudahan tersebut akan dapat menghancurkan karakter mereka. 
Kemudahan yang seharusnya membawa dampak positif justru membuat karakter generasi muda menjadi rusak. Namun, generasi sebelumnya tidak tinggal diam. Harus ada respon aktif dalam mencegah dampak buruk yang menghantui generasi muda. Mereka mencoba membantu melalui jalur pendidikan. Melalui jalur pendidikan ini, generasi muda tidak hanya diajarkan untuk menjadi pribadi yang pandai dalam akademik, namun juga diajarkan untuk memiliki karakter yang baik. Keberlangsungan bangsa ini sangat ditentukan oleh karakter yang dimiliki oleh generasi penerus bangsa (Muchtar \& Suryani, 2019). Apabila Pendidikan berhasil sampai kepada tujuan karakter, maka masa depan bangsa pasti baik.

Langkah yang diambil melalui jalur pendidikan ini adalah dengan membuat pendidikan karakter melalui setiap institusi pendidikan yang ada. Pendidikan karakter didefinisikan sebagai suatu sistem pendidikan dengan penanaman nilai-nilai sesuai dengan budaya bangsa dengan komponen aspek pengetahuan (cognitive), sikap perasaan (affection felling), dan tindakan, baik terhadap Tuhan Yang Maha Esa (YME) baik untuk diri sendiri, masyarakat dan bangsanya (Muchtar \& Suryani, 2019). Setiap pendidik akan menanamkan nilai-nilai yang baik kepada setiap peserta didik yang ada melalui proses pengajaran yang mereka lakukan. Walaupun demikian, kendala tetap terjadi dalam proses pendidikan karakter tersebut. Peserta didik yang telah diberikan pendidikan karakter tetap melakukan hal-hal yang tidak seharusnya. Contoh dari kenakalan yang mereka adalah peserta didik yang mencari kemudahan, bahkan hingga menghalalkan segala cara seperti menyontek, membeli ijazah paslu, bahkan membayar joki untuk menggantikan mereka dalam suatu ujian (Sidjabat, 2019).

Kendala yang terjadi dapat disebabkan oleh berbagai macam faktor. Salah satu faktor yang dapat menjadi penyebab adalah faktor lingkungan. Generasi Z merupakan generasi yang lahir pada tahun 1995 hingga 2010. J. J. Arnett menjelaskan ciri utama dari masa dewasa awal sebagai masa dimana mereka mengeksplorasi identitas dan masa ketidakstabilan (Arnett, 2015). Hasil penelitian dari Kaspersky Lab menyatakan bahwa generasi $\mathrm{Z}$ merupakan kelompok yang memiliki tingkat kecemasan tertinggi pada saat ini (Nursalikah, 2018). Mereka berusaha menampilkan citra sempurna. Bahkan mereka rela menyediakan waktu untuk mengedit foto-foto mereka agar mendapatkan citra yang sempurna. Hal tersebut merupakan bentuk tindakan mereka agar mereka dapat diterima dalam lingkungan mereka (Sumardianta \& Kris, 2018).

Kebijakan Nasional Pembangunan Karakter Bangsa Tahun 2010-2025, menjelaskan bahwa karakter merupakan hasil keterpaduan dari empat bagian, yaitu olah hati, olah pikir, olah raga, serta olah rasa dan karsa (Kurikulum, 2010). Berdasarkan kebijakan tersebut, setiap institusi pendidikan mencoba untuk membuat suatu strategi untuk dapat membantu generasi muda. Strategi tersebut diatur dalam fungsi manajemen yang meliputi perencanaan, pengorganisasian, penggerakan, dan pengawasan (Abbas, 2014). Institusi pendidikan merancang strategi yang ada berdasarkan visi dan misi yang dimiliki oleh institusi pendidikan tersebut (Wibowo, 2012). Oleh sebab itu, setiap institusi pendidikan tersebut akan memiliki ciri khas yang berbeda-beda. Setiap institusi pendidikan akan berusaha menekankan apa yang menjadi visi dan misi mereka ke dalam program studi dan juga fasilitas-fasilitas yang disediakan (Wahyu, 2011).

Universitas Pelita Harapan merupakan salah satu universitas swasta yang berada di Banten. Sebagai suatu universitas Kristen, Universitas Pelita Harapan menekankan nilai-nilai firman Tuhan dalam setiap kegiatan yang ada. Universitas Pelita Harapan memiliki visi yaitu menjadi Universitas yang berpusat pada Kristus, yang dibangun dan 
dikembangkan di atas dasar pengetahuan sejati, iman dalam Kristus, dan karakter ilahi, dengan tujuan menghasilkan pemimpin masa depan yang takut akan Tuhan, kompeten, dan profesional melalui pendidikan yang unggul, holistis dan transformasional (Harapan, n.d.). Visi tersebut membawa Universitas Pelita Harapan membentuk strategi yang sesuai untuk membantu para peserta didik yang ada mencapai kepada visi tersebut. Salah satu strategi yang dilakukan adalah melalui proses bimbingan dan konseling bagi para mahasiswa.

Bimbingan dan konseling merupakan proses bantuan yang diberikan agar dapat membantu memaksimalkan potensi dan melakukan pengembangan bagi mahasiswa yang tergabung. Bimbingan dan konseling memiliki beberapa fungsi, yaitu fungsi pemahaman, fungsi preventif, fungsi pengembangan, fungsi perbaikan. fungsi penyaluran, fungsi adaptif, dan fungsi penyesuaian (LN \& Sugandhi, 2020). Sebagai suatu universitas Kristen, bimbingan dan konseling tersebut merupakan wujud dari pelayanan pastoral yang berada pada universitas. Seluruh nilai-nilai yang digunakan pada proses bimbingan dan konseling tersebut merupakan nila-nilai yang sesuai dengan firman Tuhan.

Mahasiswa yang baru tergabung pada suatu universitas pada umumnya berada pada usia 18 tahun. Masa tersebut merupakan masa transisi dari remaja akhir menuju kepada dewasa awal atau dewasa dini. Menurut Elizabeth B. Hurlock, masa dewasa dini dimulai pada usia 18 tahun hingga usia 40 tahun (Hurlock, 1980). Sedangkan Choate menyebutkan bahwa masa dewasa awal berada pada rentang usia 18 tahun hingga 21 tahun (Tucker \& Smith-Adcok, 2019).

Pada masa dewasa awal, mereka mulai mengalami perubahan. Masa-masa ini merupakan masa yang sangat penting bagi mereka. Apa yang ditanamkan kepada mereka pada masa ini akan mereka bawa ke sepanjang kehidupan mereka (Simanjuntak, 2019). Oleh sebab itu, sangatlah penting penanaman nilai-nilai kehidupan dan karakter yang sesuai dengan nilai-nilai firman Tuhan ditanamkan kepada mereka pada masa ini (Minggus Dilla, 2015). Chickering membagi proses perkembangan pada masa dewasa awal menjadi tujuh vektor, yaitu mengembangkan kompetensi, mengelola emosi, saling ketergantungan, membangun identitas, membangun hubungan antar pribadi, membangun tujuan, dan membangun integritas (Tucker \& Smith-Adcok, 2019). Ketujuh faktor tersebut saling berhubungan satu dengan lainnya dan perlu dipenuhi pada masa dewasa awal.

Tindakan diatas merupakan langkah yang juga dilakukan oleh Universitas Pelita Harapan. Mereka berusaha menanamkan nilai-nilai firman Tuhan kepada seluruh mahasiswa yang ada. Berbagai bentuk bimbingan dan konseling diberikan agar mahasiswa yang ada dapat bertumbuh sesuai dengan nilai-nilai firman Tuhan. Walaupun demikian, bukan berarti tidak terdapat permasalahan. Terdapat mahasiswa-mahasiswa yang melakukan pelanggaran dari peraturan lembaga yang ada. Pada umumnya, menyontek dan melakukan plagiarisme merupakan pelanggaran yang dilakukan oleh mahasiswa. Hal tersebut mungkin terjadi karena sebagai seseorang yang berada pada masa dewasa awal, mereka masih mengalami perkembangan korteks prefrontal otak yang maksimal (Tucker \& Smith-Adcok, 2019). Kondisi tersebut berakibat kepada cara mereka memutuskan. Mereka akan lebih tertarik kepada imbalan yang akan mereka dapatkan saat melakukan sesuatu daripada konsekuensi yang mereka dapatkan. Pada masa tersebut, mereka masih memfokuskan kepada keuntungan yang ada dibandingkan dengan konsekuensi yang harus mereka tanggung. Oleh sebab itu, proses pendidikan karakter yang ada harus terus berlangsung. Para pemberi bimbingan dan konseling pun harus memiliki kesabaran dalam melakukan bimbingan dan konseling tersebut.

Penelitian ini hendak mengungkap implementasi bimbingan dan konseling bagi mahasiswa di Universitas Pelita Harapan dalam menunjang perkembangan karakter mahasiswa dan apa saja yang menjadi faktor penghambat dalam pelaksanaan proses bimbingan dan konseling bagi mahasiswa Universitas Pelita Harapan. Penelitian terkait 
penanaman godly character pernah dilakukan oleh (Zendrato, Suharno, \& Agung, 2020) yang mendorong agar sekolah memasukkan materi karakter dalam setiap mata pelajarannya. Penelitian ini dilakukan dengan metode kualitatif studi kasus di SMP Kalam Kudus, Surakarta. Lain halnya dengan (Sukardi, 2016) yang memotret godly character dari sudut pandang Islam dan (Mukhlas, 2018) yang mengimplementasikannya Madrasah Aliyah Negeri 1 Ponorogo. Dari beberapa penelitian, belum ada yang membahas mengenai Godly character dari sisi bimbingan dan konseling. Oleh karena itu, tujuan dari penelitian ini adalah untuk menganalisis secara mendalam bagaimana implementasi bimbingan dan konseling bagi mahasiswa di Universitas Pelita Harapan dalam menunjang perkembangan karakter mahasiswa dan mengidentifikasi secara mendalam faktor-faktor apa saja yang menjadi penghambat dalam pelaksanaan proses bimbingan dan konseling bagi mahasiswa Universitas Pelita Harapan.

\section{METODE PENELITIAN \\ Rancangan Penelitian}

Penelitian ini menggunakan metode kualitatif fenomenologi. Tujuan penelitian kualitatif dengan model atau rancangan fenomenologi adalah memahami esensi (hakekat) tentang pengalaman dunia terdalam individu (inner world) tentang suatu fenomena berdasarkan perspektif individu itu sendiri (Hanurawan, 2012). Teknik ini digunakan untuk mengungkapkan data lapangan secara apa adanya yang dihubungkan dengan pembangunan karakter yang semestinya (Sugiyono, 2015).

\section{Sumber Data}

Subjek dari penelitian ini adalah dosen-dosen yang juga merupakan penasihat akademik, dosen bimbingan konseling, mahasiswa Universitas Pelita Harapan, dan juga pengurus organisasi spiritual growth for student. Pemilihan subjek penelitian tersebut dilakukan dengan melihat siapa saja yang terlibat langsung dalam proses bimbingan dan konseling, yaitu pihak yang memberikan bimbingan dan konseling, dan juga pihak yang menerima bimbingan dan konseling (Tohirin, 2016).

\section{Teknik Pengumpulan Data}

Teknik pengumpulan data yang digunakan dalam penelitian ini adalah wawancara. Wawancara yang digunakan adalah mendalam (indepth intervier) secara tidak terstruktur (Gumilang, 2016). Wawancara dilakukan dengan menggunakan teknik triangulasi, dimana selain dengan pemberi dan penerima bimbingan dan konseling, wawancara juga dilakukan kepada pakar dalam bidang bimbingan dan konseling untuk mendapatkan sudut pandang lainnya yang dapat melengkapi temuan penelitian ini.

\section{Teknik Analisis Data}

Teknik analisa data dilakukan dengan mereduksi data hasil wawancara. Data yang telah direduksi dikelompokkan dan disajikan dalam bentuk yang mudah dipahami. Uji validasi dan reabilitas data juga dilakukan kepada hasil temuan yang ada. Analisis data dalam penelitian kualitatif dilakukan melalui prosedur pengembangan pola, tema, dan ciriciri umum. Oleh karena itu, tiga alur analisis yang peneliti lakukan dalam kajian ini menggunakan (Ridder, Miles, Michael Huberman, \& Saldaña, 2014) yaitu reduksi data, penyajian data, dan penarikan kesimpulan. 


\section{HASIL DAN PEMBAHASAN}

Implementasi Bimbingan \& Konseling Bagi Mahasiswa Universitas Pelita Harapan Institusi pendidikan yang baik dan benar tidak hanya memberikan ilmu pengetahuan kepada para peserta didik yang ada. Mereka juga memberikan bimbingan dan konseling kepada para peserta didik yang ada. Implementasi bimbingan dan konseling yang dilakukan tidak hanya untuk membantu mahasiswa yang memiliki masalah. Namun, juga untuk membantu mahasiswa untuk memperoleh pengembangan yang optimal. Pelaksanaan implementasi bimbingan dan konseling tersebut dimulai dengan membuat strategi, menetapkan target, pelaksanaan, dan evaluasi berdasarkan apa yang telah dilaksanakan.

\section{Perencanaan Strategi Bimbingan dan Konseling}

Strategi bimbingan dan konseling pada Universitas Pelita Harapan dibuat sesuai dengan visi dan misi yang dimilikinya. Universitas Pelita Harapan mempunyai visi yaitu menjadi Universitas yang berpusat pada Kristus, yang dibangun dan dikembangkan di atas dasar pengetahuan sejati, iman dalam Kristus, dan karakter ilahi. Tujuan dari visi ini adalah untuk menghasilkan pemimpin masa depan yang takut akan Tuhan, kompeten, dan profesional melalui pendidikan yang unggul, holistis dan transformasional. Berdasarkan visi yang dimiliki oleh Universitas Pelita Harapan, bimbingan dan konseling yang dilakukan disesuaikan dengan dasar nilai-nilai firman Tuhan. Proses bimbingan dan konseling tersebut merupakan bentuk pelayanan pastoral yang dilakukan oleh Universitas Pelita Harapan (Sugiono \& Hardori, 2020).

Menurut kepala bidang Bimbingan Konseling, strategi bimbingan dan konseling yang dirancang oleh Universitas Pelita Harapan melibatkan berbagai pihak. Hal tersebut dilakukan untuk membantu setiap pemberi bimbingan dan konseling agar dapat memberikan penanganan yang maksimal, sesuai dengan bidang keahlian mereka masingmasing. Pelaksanaan bimbingan dan konseling dilakukan sesuai dengan standard operating procedure agar setiap mahasiswa dapat dilayani sesuai dengan standar yang ada.

\section{Target Capaian}

Target yang ingin dicapat dari proses bimbingan dan konseling yang ada pada Unversitas Pelita Harapan adalah untuk menanamkan karakter ilahi kepada mahasiswa. Karakter ilahi yang dimaksud adalah kesimbangan antara kasih dan juga kedisiplinan. Karakter ilahi tersebut akan menjadi modal untuk para mahasiswa agar dapat menjalankan kehidupan mereka dengan lebih baik, dimana mereka tidak hanya menjadi seseorang yang pandai. Mahasiswa diharapkan dapat menjadi seseorang yang berguna di masyarakat, dimana mereka menjadi pribadi yang memiliki kepedulian terhadap sesama (Zahir, Srirahayu, \& Ali, 2016) dan juga berani berpegang kepada nilai-nilai yang sesuai dengan firman Tuhan.

\section{Penujang Akademik}

Penunjang akademik merupakan pihak-pihak dan fasilitas-fasilitas yang mendukung berlangsungnya proses akademik. Penunjang akademik difokuskan kepada pihak-pihak dan fasilitas-fasilitas yang mendukung dalam proses bimbingan dan konseling bagi mahasiswa.

a. Dosen Penasihat Akademik

Tugas utama seorang dosen adalah melakukan Tri Dharma, yaitu pengajaran, penelitian, dan pengabdian masyarakat. Namun, seorang dosen juga dapat menjadi seorang penasihat akademik. Penasihat akademik memiliki tugas untuk membantu mahasiswa dalam hal akademik. Penasihat akademik pada Universitas Pelita Harapan 
tidak hanya bertugas untuk mengajarkan pengetahuan akademik, namun juga nilai-nilai firman Tuhan. Mereka menanamkan nilai-nilai tersebut kepada setiap mahasiswa yang ada. Agar proses bimbingan dan konseling dapat diterima oleh seluruh mahasiswa, nilainilai firman Tuhan pada proses bimbingan dan konseling diberikan dalam bentuk pesan moral.

b. Organisasi Rohani Spiritual Growth for Student

Spiritual growth for student merupakan organisasi kerohanian yang terdapat pada Universitas Pelita Harapan. Organisasi ini dipimpin oleh mahasiswa yang tergabung pada Universitas Pelita Harapan. Organisasi spiritual growth for student memfokuskan kepada beberapa kegiatan, yaitu ibadah, doa, dan pemuridan. Ibadah yang dibuat digunakan sebagai sarana untuk menjangkau mahasiswa Universitas Pelita Harapan. Melalui kegiatan doa bersama, mahasiswa yang ada belajar untuk membangun hubungan dengan Tuhan. Melalui pemuridan, mahasiswa diberikan bimbingan sehingga dapat bertumbuh di dalam Kristus. Melalui pemuridan tersebut, mahasiswa yang ada dapat menerima proses bimbingan dan konseling. Proses bimbingan dan konseling pada organisasi spiritual growth for student menekankan pertumbuhan rohani mahasiswa dengan melakukan pendalaman firman Tuhan (Amos Hosea, 2019).

\section{c. Asrama}

Mahasiswa yang berkuliah pada Universitas Pelita Harapan pada umumnya berasal dari berbagai daerah di luar Tangerang. Pada umumnya, mereka menyewa tempat kost, ataupun apartemen di lingkungan sekitar universitas. Asrama merupakan salah satu pilihan tempat tinggal yang ada pada lingkungan universitas. Asrama bukan saja tempat mereka untuk tinggal selama mereka berkuliah, namun juga merupakan tempat dimana mereka dibimbing dan ditanamkan nilai-nilai firman Tuhan. Asrama pada Universitas Pelita Harapan memiliki bentuk yang cukup berbeda. Asrama ini merupakan tempat tinggal dari para remaja SMA yang bersekolah pada UPH College. Pada asrama ini, terdapat pembina para remaja tersebut yang merupakan mahasiswa dari Universitas Pelita Harapan. Proses bimbingan dan konseling bagi mahasiswa yang ada pada asrama bukan hanya menekankan kedisiplinan dan kemandirian pribadi, namun juga kepedulian kepada orang sesamanya dan bagaimana menjadi pemimpin yang baik.

d. Lembaga Konseling HOPE

Lembaga konseling HOPE merupakan lembaga konseling yang berada pada lingkungan Universitas Pelita Harapan. Lembaga tersebut melayani baik mahasiswa maupun staf yang memerlukan pelayanan konseling. Pelayanan pada lembaga ini dilakukan dengan dasar nilai- nilai firman Tuhan. Pada umumnya, mahasiswa yang ditangani melalui lembaga ini merupakan mahasiswa yang direferal. Mahasiswa yang direferal pada umumnya memiliki permasalahan klinis. Mahasiswa tersebut pada umumnya telah mendapatkan pertolongan, baik dari jurusan maupun organisasi dimana mereka tergabung. Namun, dikarenakan pemberi pertolongan membutuhkan bantuan dari pihak profesional dalam penanganannya, maka mahasiswa tersebut diarahkan kepada lembaga konseling HOPE. Proses konseling yang diberikan oleh lembaga konseling HOPE merupakan proses konseling profesional.

\section{Bentuk Pelaksanaan}

Pelaksanaan dari proses bimbingan dan konseling mahasiswa dapat dilakukan dalam berbagai macam bentuk. Bentuk-bentuk tersebut disesuaikan dengan kebutuhan dari masing-masing mahasiswa dan permasalahan apa yang dihadapi oleh 
mahasiswa tersebut.

a. Pendekatan Melalui Peraturan Lembaga

Proses bimbingan dan konseling dapat dilakukan melalui pendekatan peraturan lembaga. Peraturan lembaga dibuat sebagai suatu bentuk pencegahan, dimana mencegah mahasiswa yang ada melakukan suatu tindakan yang bertentangan dengan moral. Proses bimbingan dan konseling dilakukan bila mahasiswa melakukan pelanggaran peraturan lembaga. Mahasiswa yang melakukan pelanggaran akan mendapatkan pendisiplinan. Pendisiplinan yang dimaksud adalah pemberian sanksi, dan juga pemberian bimbingan dan konseling. Bimbingan dan konseling pada mahasiswa dalam masalah ini pada umumnya adalah penanaman pentingnya integritas dalam melakukan segala sesuatu. Selain itu, mahasiswa juga diajarkan untuk dapat bertanggung jawab atas tindakannya. b. Nasihat

Pemberian nasihat merupakan salah satu bentuk dari bimbingan dan konseling yang diberikan kepada mahasiswa. Nasihat diberikan kepada mahasiswa yang tidak melakukan pelanggaran. Pada umumnya, mahasiswa dengan permasalahan akademik atau permasalahan prestasi mahasiswa yang akan mendapatkan bimbingan dan konseling tersebut. Pada umumnya peremasalahan ini disebabkan oleh karena mata kuliah yang sulit, kemalasan mahasiswa, paksaan dari orangtua untuk berkuliah pada jurusan yang tidak diingininya, permasalahan keluarga, dan juga gangguan mental yang dialami mahasiswa. Proses bimbingan dan konseling dilakukan dengan cara membangun semangat juang dari mahasiswa (Rumahorbo \& Manalu, 2016).

c. Pemuridan

Proses pemuridan dalam organisasi spiritual growth for student ini memiliki penekanan kepada nilai-nilai firman Tuhan. Bimbingan yang diberikanpun lebih berhubungan dengan pertumbuhan rohani mahasiswa. Walaupun demikian, mahasiswa yang ada dapat menceritakan setiap permasalahan mereka. Proses bimbingan pada organisasi ini pada umumnya diberikan oleh ketua kelompok kecil yang ada. Ketua kelompok kecil tersebut merupakan mahasiswa yang tergabung dalam organisasi spiritual growth for student. Oleh karena itu, proses bimbingan pada organisasi ini diberikan oleh teman sebaya. Bila ketua kelompok kecil tersebut memiliki kendala pada saat proses bimbingan diberikan, maka ketua kelompok tersebut dapat berkonsultasi kepada pembinanya, yang pada umumnya merupakan dosen universitas tersebut. Pemberian bimbingan dalam bentuk pemuridan lebih difokuskan kepada penanaman nilai-nilai firman Tuhan dan juga pendalaman Alkitab.

\section{d. Learning by Doing}

Mahasiswa pada Universitas Pelita Harapan diberikan bimbingan agar mereka bukan hanya pandai, namun juga memiliki kepedulian. Langkah yang diambil oleh universitas adalah melalui kelas yang diadakan oleh divisi student life. Mata kuliah service-learning project yang diadakan oleh divisi student life merupakan mata kuliah yang berhubungan dengan pelayanan masyarakat. Mahasiswa memiliki tugas untuk membuat suatu pelayanan masyarakat, seperti membantu panti asuhan, membuat lampu jalan, dan memberikan sumbangan buku untuk perpustakaan. Mahasiswa diajarkan mengenai kepedulian terhadap masyarakat yang ada di sekitar mereka melalui mata kuliah ini (Usman, 2020).

Projek yang ada dimulai dengan membuat proposal terlebih dahulu. Mahasiswa juga melakukan tinjauan terlebih dahulu ke tempat dimana mereka akan melakukan projek mereka. Mahasiswa juga mengumpulkan dana secara mandiri yang nantinya akan digunakan dalam pelaksanaan projek ini. Hal ini dilakukan agar mahasiswa menyadari bahwa apa yang mereka lakukan dapat menjadi berkat bagi orang lain. Laporan dari projek ini dibuat sebagai bentuk penilaian dari apa yang telah mereka lakukan.

e. Bimbingan Kolaboratif Lembaga

Bimbingan kolaboratif lembaga dilakukan oleh para pemberi bimbingan dan konseling yang berada pada Universitas Pelita Harapan. Kolaborasi dilakukan oleh 
dosen, penasihat akademik, ataupun organisasi dimana mahasiswa tersebut tergabung dengan lembaga konseling HOPE. Kolaborasi dilakukan karena tidak semua pemberi bimbingan dan konseling yang ada pada Universitas Pelita Harapan merupakan konselor professional yang dapat menangani permasalahan klinis (Fathurrohman, 2014).

Kolaborasi dilakukan dengan cara memberikan informasi bagaimana cara memberikan bantuan untuk mahasiswa yang bersangkutan. Kerjasama juga dilakukan dengan orangtua dari mahasiswa tersebut. Pemberian informasi dilakukan karena tidak semua pemberi bimbingan memiliki ilmu yang diperlukan untuk memberikan bimbingan tersebut. Kerahasiaan tetap dijaga oleh pihak-pihak yang memberikan bimbingan dan konseling. Pemberian informasi hanya dilakukan kepada pihak yang akan bekerjasama dalam memberikan bimbingan dan konseling.

\section{f. Support Academic}

Support academic yang dimaksud merupakan bagian dari universitas yang mendukung proses akademik. Asrama merupakan support academic yang ada pada Universitas Pelita Harapan. Mahasiswa yang tergabung dalam asrama akan wajib mengikuti kegiatan-kegiatan yang ada di asrama. Mahasiswa yang tergabung dalam asrama dilatih untuk memiliki kemandirian. Mahasiswa yang tergabung dalam asrama tersebut juga memiliki tugas untuk menjadi pembina bagi para remaja SMA yang tergabung pada asrama tersebut.

Melalui sistem yang ada pada asrama ini, mahasiswa belajar bagaimana mengatasi permasalahan yang terjadi pada saat membina para remaja SMA yang menjadi anggotanya. Dorm parrent juga memberikan pendampingan kepada mahasiswa yang menjadi Pembina. Proses bimbingan yang berada pada asrama ini tidak hanya membuat mahasiswa yang ada menjadi mandiri, namun juga menjadi dewasa dan mampu menghadapi permasalahan yang ada dengan cara yang tepat.

\section{Faktor-faktor Hambatan Proses Bimbingan \& Konseling Bagi Mahasiswa Universitas Pelita Harapan}

Hambatan dalam proses bimbingan dan konseling dapat terjadi baik dari sisi penerima bimbingan dan konseling, maupun sisi pemberi bimbingan dan konseling. Hambatan tersebut membuat pemberian bimbingan dan konseling menjadi tidak maksimal.

\section{Kompetensi SDM Dalam Penanganan Masalah Mahasiswa}

Hambatan utama dari para pemberi pertolongan pada universitas adalah karena tidak memiliki pengetahuan yang memadai bagaimana cara untuk memberikan bimbingan dan konseling kepada mahasiswa. Hal ini dikarenakan setiap pemberi bimbingan dan konseling memiliki keahlian yang berbeda dalam bidangnya. Mereka bukan seseorang yang memang secara khusus bergerak dalam bidang bimbingan dan konseling. Mereka juga tidak memiliki pengetahuan mengenai ilmu psikologi. Hal tersebut menyebabkan tidak terpenuhinya kebutuhan dari penerima bimbingan dan konseling, yaitu kebutuhan untuk dapat dimengerti (Sukartini, 2018).

\section{Mahasiswa Yang Kurang Berminat Dengan Program Bimbingan \& Konseling}

Mahasiswa melihat proses bimbingan dan konseling sebagai sesuatu yang negatif. Mahasiswa memandang bahwa mahasiswa yang memiliki masalah yang akan mendapatkan proses bimbingan dan konseling. Terdapat beberapa alasan mengapa mahasiswa yang ada menghindari proses bimbingan dan konseling. Perasaan malu terhadap apa yang dialami membuat mahasiswa yang ada menjadi tertutup dan 
menghindari proses bimbingan dan konseling. Mahasiswa juga memiliki perasaan takut akan dihakimi bila dirinya menceritakan apa yang menjadi permasalahannya. Mahasiswa juga menghindari proses bimbingan dan konseling karena merasa hanya akan menambah permasalahan bila menceritakannya kepada orang lain. Hal tersebut dapat terjadi bila mahasiswa yang ada bercerita kepada orang yang salah, sehingga mendapatkan masukan yang tidak baik.

\section{Mahasiswa Yang Belum Dapat Bersifat Dewasa}

Mahasiswa yang belum dapat bersifat dewasa terlihat pada mahasiswa yang masih memperhitungkan untung dan rugi dalam melakukan sesuatu. Mahasiswa berani untuk melanggar peraturan lembaga hanya untuk mendapatkan keuntungan dibalik suatu hal. Mereka akan mencoba memperhitungkan apakah keuntungan yang akan diperoleh dapat lebih besar daripada kerugiannya. Walaupun sanksi telah diberikan kepada mahasiswa yang melakukan pelanggara, namun keinginan untuk melakukan hal yang sama tetap dapat terjadi. Para pemberi bimbingan dan konseling berpikir bagaimana cara yang dapat diterima oleh mahasiswa agar tidak melakukan pengulangan kembali. Salah satu cara yang dilakukan adalah dengan memperketat peraturan yang ada.

\section{Pembahasan Hasil Penelitian}

Sebagai suatu institusi pendidikan, pendidikan karakter merupakan sesuatu yang perlu ditanamkan kepada mahasiswa sesuai dengan arahan pemerintah. Universitas Pelita Harapan sebagai universitas Kristen menekankan nilai-nilai kekristenan pada setiap program yang ada. Dengan kata lain, Universitas Pelita Harapan menekankan nilai religiositas sebagai nilai utama. Hal tersebut sesuai dengan yang dijelaskan oleh Koesoema dimana nilai karakter dalam hubungan dengan Tuhan menjadi prioritas utama yang perlu diberikan kepada mahasiswa yang ada (Koesoema, 2015).

Proses bimbingan dan konseling yang diberikan kepada mahasiswa tetap menekankan kasih dan juga pendisiplinan. Hal tersebut dilakukan karena para pemberi bimbingan dan konseling menganggap mahasiswa yang ada sebagai anak- anaknya. Hal tersebut sesuai dengan firman Tuhan yang terdapat pada Amsal 13:24, yaitu "Siapa tidak menggunakan tongkat, benci kepada anaknya; tetapi siapa mengasihi anaknya, menghajar dia pada waktunya" (Collins, 2017).

Pemberi bimbingan dan konseling pada Universitas Pelita Harapan pada umumnya tidak memiliki latar belakang pendidikan bimbingan dan konseling. Prof. Dr. H. Syamsu Yusuf LN., M.Pd. dan Dr. Nani M. Sugandhi menyebutkan bahwa tenaga ahli yang berwenang dalam memberikan bimbingan dan konseling merupakan dosen dengan latar belakang pendidikan dalam bidang bimbingan dan konseling atau seorang psikolog. Walaupun demikian, para pemberi bimbingan dan konseling tetap bekerjasama dengan lembaga konseling HOPE. Melalui kerjasama yang dilakukan tersebut, para pemberi bimbingan dan konseling non profesional dapat terbantu untuk menangani mahasiswa yang ada dengan cara yang tepat.

Pemberian pertolongan kepada mahasiswa yang mereka berikan adalah bimbingan dalam bentuk seperti teaching, mentoring, maupun coaching. Teaching merupakan proses bimbingan dan konseling yang dilakukan dalam bentuk nasihat satu arah. Mentoring merupakan proses bimbingan dan konseling dalam bentuk pemuridan pada organisasi spiritual growth for student. Sedangkan coaching merupakan proses bimbingan melalui kegiatan yang diberikan pada student life (Aly, 2017).

Kompetensi SDM yang memberikan layanan bimbingan dan konseling pada Universitas Pelita Harapan merupakan salah satu faktor yang menjadi penghambat. Pihak pemberi bimbingan membutuhkan kemampuan untuk dapat mengerti mahasiswa. Hal tersebut sesuai dengan teori komunikasi yang dikatakan oleh Charles H. Kraft., yaitu agar pesan yang kita berikan dapat diterima oleh penerima pesan, maka kita perlu berorientasi pada penerima pesan tersebut (Kraft, 2002). Berorientasi pada penerima 
pesan adalah upaya untuk menyesuaikan diri kita kepada penerima pesan tersebut, baik dalam sikap maupun cara menyampaikan pesan tersebut.

Ketidakdewasaan mahasiswa terlihat dari tindakan mahasiswa yang masih melihat untung dan ruginya dalam melakukan suatu pelanggaran. Hal tersebut karena mahasiswa yang berada pada masa dewasa awal masih mengalami perkembangan (Skeldon \& Waller, 2020). Berdasarkan hasil riset mengenai otak, korteks prefrontal otak pada masa belum sepenuhnya tertata dan berkembang hingga masa pertengahan hingga akhir 20-an (Tucker \& Smith-Adcok, 2019). Hal tersebut menyebabkan mereka yang berada pada masa dewasa awal ini lebih memprioritaskan imbalan yang ada daripada konsekuensi yang dapat diperoleh mereka.

\section{SIMPULAN}

Implementasi bimbingan dan konseling bagi mahasiswa di Universitas Pelita Harapan dalam menunjang perkembangan karakter mahasiswa dibuat sesuai dengan visi yang dimiliki oleh Universitas Pelita Harapan adalah dengan memprioritaskan nilai-nilai firman Tuhan sesuai dengan target yang ingin dicapai agar mahasiswa memiliki karakter ilahi. Proses bimbingan dan konseling dilakukan oleh pihak non profesional, seperti penasihat akademik, organisasi rohani spiritual growth for student, dan pihak yang berada pada asrama; dan juga dilakukan oleh pihak profesional, yaitu lembaga konseling HOPE. Bimbingan dan konseling dilakukan dalam beberapa bentuk, yaitu pendekatan peraturan lembaga, pemberian nasihat, pemuridan melalui organisasi spiritual growth for student, sistem learning by doing dari divisi student life, bimbingan kolaboratif Lembaga, dan melalui support academic.

Faktor-faktor yang menjadi penghambat dalam pelaksanaan proses bimbingan dan konseling adalah kompetensi SDM dalam penanganan mahasiswa yang masih belum memadai, mahasiswa yang kurang berminat kepada program bimbingan dan konseling; yang disebabkan oleh perasaan malu terhadap apa yang dialami, perasaan takut dihakimi, tidak ingin menambah masalah akibat melakukan bimbingan dan konseling; dan mahasiswa yang belum dapat bersifat dewasa

\section{UCAPAN TERIMAKASIH}

Puji syukur penulis naikan kepada Tuhan yang telah menolong pekerjaan penelitian ini. Penulis berterima kasih kepada unsur pimpinan STT Bethel Indonesia yang telah mendukung untuk melaksanakan penelitian ini. Demikian dengan para dosen yang telah mengarahkan kajian ini sehingga dapat saling memperlengkapi dan menjadi penelitian bersama.

\section{DAFTAR PUSTAKA}

Abbas, S. (2014). Manajemen Perguruan Tinggi: Beberapa Catatan. Jakarta: Kencana. Aly, A. (2017). Pengembangan Pembelajaran Karakter Berbasis Soft Skills Di Perguruan Tinggi. Ishraqi, 1(1), 18-30.

Amos Hosea. (2019). Karakteristik Pendidikan Iman dalam Pentakostalisme. Diegesis : Jurnal Teologi. https://doi.org/10.46933/dgs.vol4i251-57

Arnett, J. J. (2015). The Emerging Adult: The Winding Road From The Late Teens Through The 20's. New York: Oxford University Press. 
Benyamin, P. I., Sinaga, U. P., \& Gracia, F. Y. (2021). Use of Digital "Platforms" in Christian Religious Education Learning in the Era of Disruption [Penggunaan "Platform" Digital pada Pembelajaran Pendidikan Agama Kristen di Era Disrupsi]. REGULA FIDEI: Jurnal Pendidikan Agama Kristen, 6(1), 60-68.

Collins, G. R. (2017). Konseling Kristen yang Efektif. Malang: Literatur SAAT.

Fathurrohman, P. (2014). Urgensi Bimbingan \& Konseling Di perguruan Tinggi. Bandung: Refika Aditama.

Gumilang, G. S. (2016). Metode Penelitian Kualitatif dalam Bidang Bimbingan dan Konseling. Jurnal Fokus Konseling, 2(2), 144-159. Retrieved from http://ejournal.usd.ac.id/index.php/LLT\%0Ahttp://jurnal.untan.ac.id/index.php/jpdpb/ar ticle/viewFile/11345/10753\%0Ahttp://dx.doi.org/10.1016/j.sbspro.2015.04.758 $\% 0$ Awww.iosrjournals.org

Hanurawan, F. (2012). Metode Penelitian Kualitatif dalam Ilmu Psikologi. Surabaya: Komisi Peningkatan Kinerja Masyarakat (KPKM) Universitas Airlangga.

Harapan, U. P. (n.d.). Siapa, Apa, dan Kenapa. Retrieved May 5, 2021, from Harapan, Universitas Pelita website: https://www.uph.edu/id/about-us/our-purpose/

Hurlock, E. B. (1980). Psikologi Perkembangan. Jakarta: Erlangga.

Koesoema, D. (2015). Pendidikan Karakter Utuh dan Menyeluruh. Yogyakarta: Kanisius. Kraft, C. H. (2002). Berkomunikasi Dengan Kuasa. Malang: Gandum Mas.

Kurikulum, K. P. N. B. P. dan P. P. (2010). Bahan Pelatihan Penguatan Metodologi Pembelajaran Berdasarkan Nilai-Nilai Budaya Untuk Membentuk Daya Saing Dan Karakter Bangsa. Pengembangan Pendidikan dan Karakter Bangsa. Jakarta: Kemendiknas.

LN, S. Y., \& Sugandhi, N. M. (2020). Bimbingan Dan Konseling Di Perguruan Tinggi. Bandung: Remaja Rosdakarya.

Minggus Dilla. (2015). Makna Buah Roh Dalam Galatia 5: 22-23. Manna Rafflesia.

Muchtar, D., \& Suryani, A. (2019). Pendidikan Karakter Menurut Kemendikbud. Edumaspul: Jurnal Pendidikan, 3(2), 50-57.

Mukhlas, M. (2018). Implementation of Religion Values on Character Education for Grade 2 Students in Madrasah Aliyah Negeri 1 Ponorogo. Educan: Jurnal Pendidikan Islam, 2(1), 168-186.

Muqsith, M. A. (2019). Pemuda, Globalisasi dan Perubahan Sosial. 'Adalah, 3(4), 19-25. https://doi.org/10.15408/adalah.v3i4.17925

Nursalikah, A. (2018). Generasi Z Cemaskan Penampilan Ketimbang Karier. Retrieved May 10, 2021, from Republika.id website: https://www.republika.co.id/berita/gaya-hidup/trend/18/12/05/pj9i56366generasi-z-cemaskan-penampilan-ketimbang-karier

Ridder, H. G., Miles, M. B., Michael Huberman, A., \& Saldaña, J. (2014). Qualitative data analysis. A methods sourcebook. Zeitschrift Fur Personalforschung, 28(4), 485-487. https://doi.org/10.1177/239700221402800402

Rumahorbo, B., \& Manalu. (2016). Sistem Pakar Konsultasi Dan Konseling Mahasiswa Bermasalah Dari Prespektif Kritiani. METHODIKA, 2(1), 139-145.

Sidjabat, B. S. (2019). Kerangka Kurikulum Pendidikan Agama Kristen Berbasis Karakter di Perguruan Tinggi. Jurnal Jaffray, 17(1), 73-90.

Simanjuntak, J. (2019). Perlengkapan Seorang Konselor. Tangerang: Yayasan Pelikan.

Skeldon, G., \& Waller, R. C. (2020). Generasi Penuh Hasrat: The Passion Generation. 
Jakarta: Literatur Perkantas.

Stillman, D., \& Stillman, J. (2017). Generasi Z: Memahami Karakter Generasi Baru Yang Akan Mengubah Dunia Kerja. Jakarta: Gramedia Pustaka Utama.

Sugiono, S., \& Hardori, J. (2020). Domain Desain Pembelajaran Inkarnatif. Diegesis: Jurnal Teologi, 5(2), 14-24. https://doi.org/10.46933/dgs.vol5i214-24

Sugiyono. (2015). Metode Penelitian Kualitatif dan R and D. In Bandung: Alfabeta. Alfabeta.

Sukardi, I. (2016). Character Education Based on Religious Values: an Islamic Perspective. Ta'dib, 2l(1), 41. https://doi.org/10.19109/td.v21i1.744

Sukartini. (2018). Bimbingan Dan Konseling Berbasis Kompetensi. Depok: Rajawali Press.

Sumardianta, J., \& Kris, W. (2018). Mendidik Generasi Z\&A. Jakarta: Grasindo.

Tohirin. (2016). Metode Penelitian Kualitatif Dalam Pendidikan Dan Bimbingan Konseling. Jakarta: RajaGrafindo Persada.

Tucker, C., \& Smith-Adcok, S. (2019). Konseling Anak-Anak dan Remaja: Counseling Children And Adolescents. Yogyakarta: Pustaka Pelajar.

Usman, N. (2020). Konteks Implementasi Berbasis Kurikulum. Jakarta: Raja Grafindo Persada.

Wahyu, W. (2011). Masalah dan Usaha Membangun Karakter Bangsa. Komunitas: International Journal of Indonesian Society and Culture, 3(2), 138-149.

Wibowo, A. (2012). Pendidikan Karakter: Strategi Membangun Karakter Bangsa Berperadaban. Yogyakarta: Pustaka Pelajar.

Zahir, A., Srirahayu, A., \& Ali, B. (2016). Pengembangan karakter mahasiswa melalui praktek dunia kerja. Prosiding Seminar Nasional ISSN 2443-1109, 2(1), 636645.

Zendrato, M. D. A., Suharno, S., \& Agung, L. (2020). Development of Christian Character Education Based Project Based Learning Teaching Materials to Improve Student Character. International Journal of English Literature and Social Sciences, 5(3), 740-748. https://doi.org/10.22161/ijels.53.28

\section{PROFIL SINGKAT}

Albert Andreas adalah Alumni dari program studi pasca sarjana Konseling Pastoral Sekolah Tinggi Teologi Bethel Indonesia.

Dony Ch Chandra adalah Dosen Program Studi Pasca Sarjana Pastoral Konseling Sekolah Tinggi Teologi Bethel Indonesia. Ia aktif dalam penelitian konseling dan sedang menggarap penelitian resiliensi keluarga di daerah Papua dalam menghadapi Pandemi Covid-19. Ia juga aktif dalam kajian misiologi. Sudah meneliti misiology kepada generasi millennial yang sedang masa tunggu terbit dalam prosiding International yang diterbitkan oleh Atlantis Press.

Sussana Kathryn adalah ketua program studi pastoral konseling Sekolah Tinggi Teologi Bethel Indonesia. Aktif melakukan kajian-kajian lintas ilmu yang dikorelasikan dengan bimbingan konseling. 
Wiryohadi adalah dosen home base pasca sarjana Pastoral Konseling Sekolah Tinggi Teologi Bethel Indonesia. Aktif dalam organisasi di Badan Pekerja Harian (BPH) Gereja Bethel Indonesia. Apin Militia Christi adalah dosen tetap di STT Bethel Indonesia. Beliau juga adalah pembantu ketua (PUKET) 2 dalam organisasi STT Bethel. Aktif menulis kajian-kajian ilmiah yang diterbitkan dalam jurnal nasional dan international. Selain itu, beliau aktif menulis buku-buku referensi dalam setiap mata kuliah yang diampuhnya. 